\title{
Changes in Color Parameters during Fermentation and Storage of Red Wine Using Thai Roselle under Different $\mathbf{p H s}$ and $\mathrm{SO}_{2}$ Concentrations
}

\author{
Koki Yokotsuka, ${ }^{1}$ Mizuo YaJima, ${ }^{2}$ Tatsuji SEKI ${ }^{3}$ and Mark MatThews ${ }^{4}$ \\ ${ }^{1}$ The Institute of Enology and Viticulture, Yamanashi University, Kofu, Yamanashi 400, Japan \\ ${ }^{2}$ Asama Chemical Co., Ltd., 20-3, Nihonbashi-Kodenma-cho, Chuo-ku, Tokyo 103, Japan \\ ${ }^{3}$ International Center of Cooperative Research in Biotechnology, Osaka University, Suita, Osaka 565, Japan \\ ${ }^{4}$ Department of Viticulture and Enology, University of California, Davis, CA 95616, USA
}

Received July 31, 1996

\begin{abstract}
A red wine was made from must consisting of dried roselle calyces, water, yeast extract, sugar, and $\mathrm{NH}_{4} \mathrm{H}_{2} \mathrm{PO}_{4}$. The pHs of wine samples were adjusted to various values within the range 2.5 to 4.0 , or $\mathrm{SO}_{2}$ was added prior to yeast addition to give concentrations ranging from 0 to $250 \mathrm{mg} / l$, and the wines were stored at $25^{\circ} \mathrm{C}$. After storage for 35 months, the $\mathrm{pH}$ of each wine was regularized, and the wines were then analyzed to determine their general composition and various red color parameters. There was little difference in general composition among the wines stored under different $\mathrm{pHs}$ and containing various concentrations of $\mathrm{SO}_{2}$. There were, however, appreciable differences in color density, color hue, and polymeric pigment color, but little difference in the wine color measured at wine $\mathrm{pH}$ and at $\mathrm{pH} 0.25$, among the wines stored under different $\mathrm{pHs}$. On the other hand, there were noticeable differences in all the above color parameters, except for color hue, among the wines stored under various $\mathrm{SO}_{2}$ concentrations. Wine color and anthocyanin color were more stable in wines stored at lower pHs or at lower concentrations of $\mathrm{SO}_{2}$, whereas the degree of contribution of polymeric pigment to wine color $($ at $\mathrm{pH}<0.5)$ increased

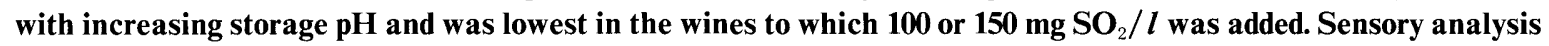
indicated that the addition of $\mathrm{SO}_{2}$ at $100 \mathrm{mg} / l$ when bottling imparted the best overall quality to the roselle wines stored under the various conditions tested.
\end{abstract}

Keywords: roselle red wine, color parameters, anthocyanins, pigments in wine

Roselle (Hibiscus sabdariffa L.) is very important in several tropical countries both as a medicinal plant and as a beverage coloring and flavoring additive (Leclerc, 1938; Sharaf, 1962; El-Merzabani et al., 1979; Perry, 1980; El-Shaveb \& Mabrouk, 1984). In Thailand, dried roselle calyces are commercially available and are used as a raw material for red wine because of the contribution of their attractive red color and flavor to the wine. Shibata and Furukawa (1969) reported the presence of cyanidin-3-glucoside $(\mathrm{Cn}-3 \mathrm{G})$, delphinidin-3-glucoside (Dp-3G), and delphinidin-3-sambubioside (Dp-3GX) as red pigments in the dried calyx and bract of roselle. Du and Francis (1973) identified cyanidin-3-sambubioside (Cn-3GX) as well as Cn-3G, Dp-3G, and Dp3GX in fresh roselle calyces. The color of red pigments such as anthocyanins in red wine is strongly influenced by the $\mathrm{pH}$ and the concentration of $\mathrm{SO}_{2}$ (Somers \& Evans, 1974, 1977; Jackson et al, 1978; Yokotsuka, 1995). The color of red wine made using roselle is labile and subject to rapid decolorization, but there has hitherto been no report on the stability of red pigments in the wine. The present study was conducted to determine the general composition of red wine made using roselle must consisting of water, roselle calyces, and sugar; the changes in total phenol and red pigment color during fermentation; and the effects of adjusting the $\mathrm{pH}$ and the amount of $\mathrm{SO}_{2}$ added just prior to bottling on the composition and color of the wine.

\section{Materials and Methods}

Winemaking Dried roselle (calyces) was purchased at a market in Bangkok, Thailand, brought to Japan, and stored in vinyl bags at $4^{\circ} \mathrm{C}$ until use.

Sugar $(20 \%, \mathrm{w} / \mathrm{v}), \mathrm{NH}_{4} \mathrm{H}_{2} \mathrm{PO}_{4}(0.05 \%, \mathrm{w} / \mathrm{v})$, and yeast extract $(0.10 \%, \mathrm{w} / \mathrm{v})$ were dissolved in $24 l$ water. The solution was divided into $12,2-l$ portions in $3-l$ glass carboys fitted with glass air locks, and dried roselle $(3 \%, \mathrm{w} / \mathrm{v})$ was added to each. One of three treatments was then instituted: potassium metabisulfite was added to give either 50 or 100 $\mathrm{mg} / \mathrm{l}$ as free $\mathrm{SO}_{2}$, or no potassium metabisulfite was added $\left(\mathrm{SO}_{2}\right.$ of $\left.0 \mathrm{mg} / l\right)$.

All the musts were allowed to stand overnight at room temperature. After the addition of $\mathrm{SO}_{2}$, the total acidity of the 12 musts was $0.68 \%$ as $\mathrm{H}_{2} \mathrm{SO}_{4}$ equivalent, and their $\mathrm{pHs}$ ranged from 2.73 to 2.76 . Active dry wine yeast of Saccharomyces cerevisiae W3 (2\%, w/v) (Yokotsuka \& Matsudo, 1992) was placed in warm water $\left(30^{-} 35^{\circ} \mathrm{C}\right)$, and the suspension was allowed to stand for $2 \mathrm{~h}$ at room temperature. This suspension $(5 \mathrm{ml})$ prepared just before use was added to each carboy with gentle stirring.

Fermentation was conducted at $25^{\circ} \mathrm{C}$. Fermenting must samples $(20 \mathrm{ml})$ were taken at appropriate time intervals and centrifuged at $31,000 \times g$ at $4^{\circ} \mathrm{C}$ for $20 \mathrm{~min}$. The supernatant obtained was filtered through a $0.45-\mu \mathrm{m}$ membrane filter. The absorbance of the filtrate at 520 and $420 \mathrm{~nm}$ was measured and analyzed for total phenols (Figs. 1 and 2). The fermenting 


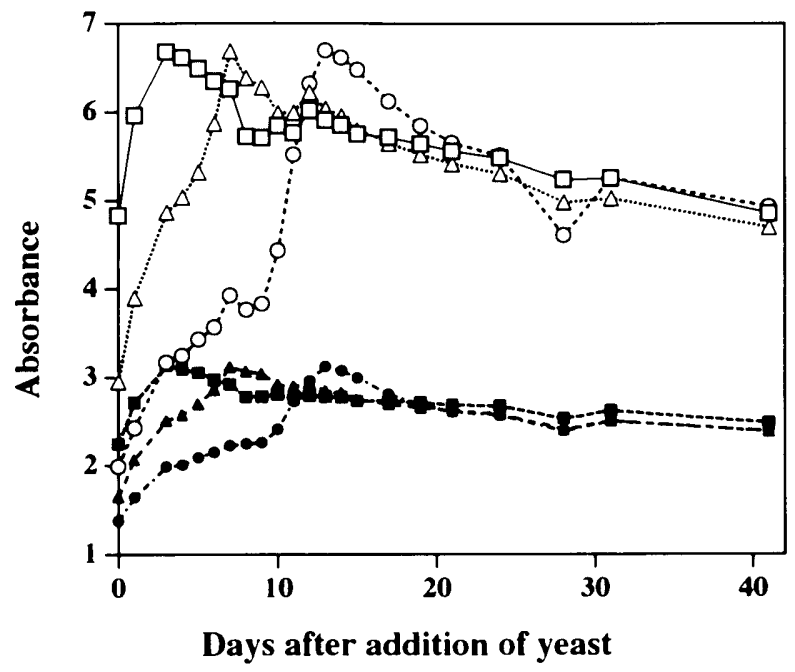

Fig. 1. Changes in absorbances at $520 \mathrm{~nm}$ and $420 \mathrm{~nm}$ during vinification of roselle red wine with various concentrations of added $\mathrm{SO}_{2} . \square, A_{520}$ at $0 \mathrm{mg}$ $\mathrm{SO}_{2} / l ; \triangle, A_{520}$ at $50 \mathrm{mg} \mathrm{SO} / l ; \bigcirc, A_{520}$ at $100 \mathrm{mg} \mathrm{SO}_{2} / l ; \mathbf{\square}, A_{420}$ at $0 \mathrm{mg} \mathrm{SO}_{2} /$ $l ; \Delta, A_{420}$ at $50 \mathrm{mg} \mathrm{SO} / l ; \bullet, A_{420}$ at $100 \mathrm{mg} \mathrm{SO}_{2} / l$.

must was pressed with a small, hand-operated basket press made of oak wood a week after the beginning of fermentation (when the formation of carbon dioxide was observed through the air locks). The fermentation was continued until the specific gravity reached about 1.00 when measured with a hydrometer. It was then stopped by removing yeast cells by centrifugation at $12,000 \times g$ followed by filtration through a $0.8-\mu \mathrm{m}$ membrane filter. The general composition of the wines was analyzed in terms of specific gravity, alcohol, total and volatile acids, reducing sugars, total and free $\mathrm{SO}_{2}$, the absorbances at 520 and $420 \mathrm{~nm}$, and total phenols immediately after filtration, according to the methods described by Amerine and Ough (1980).

In order to investigate the effects of $\mathrm{SO}_{2}$ and $\mathrm{pH}$ on the stability of the red color in roselle wine during storing, $30 l$ of the same must previously described was used. An active dry yeast suspension of Saccharomyces cerevisiae W3 (15 g/50 $\mathrm{ml}$ ), but no $\mathrm{SO}_{2}$, was added to the must. Fermentation was conducted in a $50-l$ stainless-steel tank at $25^{\circ} \mathrm{C}$, and the fermenting must was pressed as already described a week after the addition of the yeast (specific gravity, 1.027). The fermentation was stopped by removing yeast cells by centrifugation at $9,700 \times g$ with a type-H-600S centrifuge (Kokusan Enshinki Co., Ltd., Tokyo) equipped with a continuous-flow head (50 $l / \mathrm{h}$ ) followed by filtration through a $0.8-\mu \mathrm{m}$ membrane filter when the specific gravity of the fermenting must became 1.00 . The yield of the finished wine was $29.1 l$.

Storage of roselle red wine at different pHs and in the presence of various concentrations of $\mathrm{SO}_{2}$ The finished wine was split into 20 aliquots of $1.44 l$ each. The $\mathrm{pH}$ of the finished wine, $\mathrm{pH} 2.81$, was adjusted to various values ranging from 2.50 to 4.00 with aqueous $\mathrm{KOH}$ or $\mathrm{HCl}$ solution in the absence of $\mathrm{SO}_{2}$. Because the volume of $\mathrm{KOH}$ or $\mathrm{HCl}$ solution added to the 1.44- $l$ aliquots was only between 3 and $9 \mathrm{ml}$, the changes in the volumes of the wine samples were very small. Potassium metabisulfite was added to other aliquots to give concentrations of $144 \mathrm{mg}$ (total $\mathrm{SO}_{2} 44 \mathrm{mg} / l$, measured one

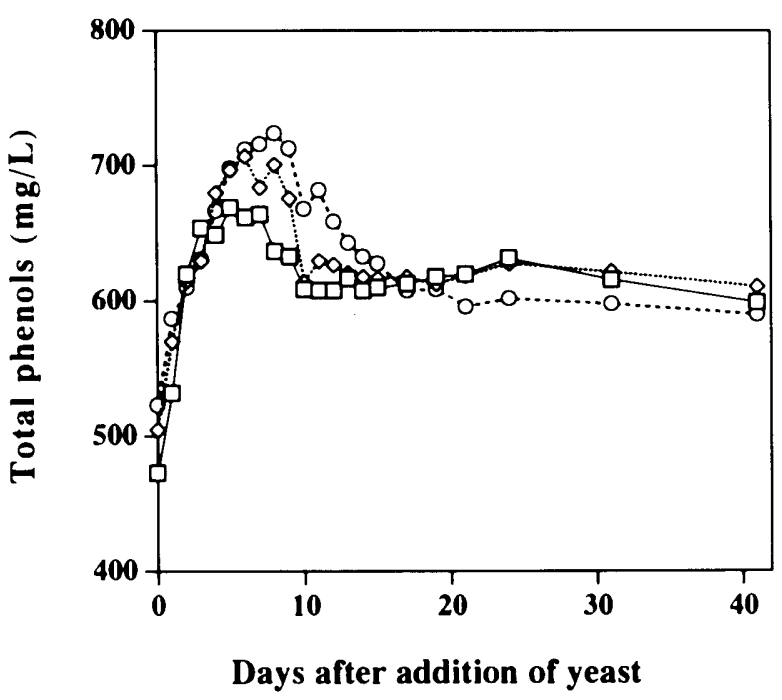

Fig. 2. Changes in total phenols during vinification of roselle red wine with $\mathrm{SO}_{2}$ added in various concentrations of added $\mathrm{SO}_{2} . \square, 0 \mathrm{mg} \mathrm{SO} / 2, \diamond, 50 \mathrm{mg}$ $\mathrm{SO}_{2} / l ; \bigcirc, 100 \mathrm{mg} \mathrm{SO}_{2} / l$.

day after addition), $288 \mathrm{mg}$ (84 mg), $432 \mathrm{mg}$ (146 mg), or 720 $\mathrm{mg}(245 \mathrm{mg})$, or no potassium metabisulfite was added $\left(\mathrm{SO}_{2}\right.$, $0 \mathrm{mg} / l)$. The wines of different $\mathrm{pHs}$ and with various concentrations of $\mathrm{SO}_{2}$ were then bottled in 720-ml screw-cap glass bottles, stored in an air temperature-controlled room at $25^{\circ} \mathrm{C}$, and analyzed for their general composition, pigment parameters, and sensory characteristics 35 months after the beginning of storage.

Phenolic and spectral analyses, and sensory evaluation Duplicate analyses of wine components were carried out, and the analytical values reported are the averages of the two samples. Total flavonoid and non-flavonoid phenols were determined according to the methods of Slinkard and Singleton (1977) and Kramling and Singleton (1969), respectively. Spectral analyses were carried out according to the methods of Somers and Evans $(1974,1977)$ and Yokotsuka (1995). Sensory evaluation of the wines was performed as described by Jackson et al. (1978).

\section{Results and Discussion}

Changes in wine color and total phenols during vinification of roselle red wine In grape must, fermentation generally begins within a few days after the addition of yeast if a normal dose of $\mathrm{SO}_{2}$ is added, the must is allowed to stand overnight, and the yeast is then added. In the case of the roselle must, fermentation began one day after the addition of yeast without $\mathrm{SO}_{2}$, but not until after 7 days with $50 \mathrm{mg}$ added $\mathrm{SO}_{2} / l$ and after $11-12$ days with $100 \mathrm{mg}$ added. This may be because the roselle must contained only small amounts of compounds, such as acetaldehyde, pyruvic acid, and $\alpha$-ketoglutaric acid, which normally react with $\mathrm{SO}_{2}$ to form bisulfite complexes (Burroughs \& Whiting, 1960), and hence, the added $\mathrm{SO}_{2}$ left in free form probably suppressed the growth of yeast cells.

The absorbance of the fermenting musts at $520 \mathrm{~nm}$ increased with time after the addition of roselle calyces to the medium consisting of water, yeast extract, sugar, and 
$\mathrm{NH}_{4} \mathrm{H}_{2} \mathrm{PO}_{4}$ (Fig. 1). The maximum values of the absorbance at $520 \mathrm{~nm}$ were obtained a few days after the beginning of fermentation, after which the absorbance gradually decreased. The trend in the changes in the absorbance at $420 \mathrm{~nm}$ was similar to that at $520 \mathrm{~nm}$, although the day on which the maximum values occurred slightly differed depending on the concentration of $\mathrm{SO}_{2}$ added to the must before the addition of yeast. The maximum absorbance at $520 \mathrm{~nm}$ was delayed by $\mathrm{SO}_{2}$ addition; the higher the $\mathrm{SO}_{2}$ concentration, the longer the delay, accompanied by a slight drop in the maximum values (Fig. 1). A larger amount of $\mathrm{SO}_{2}$ also delayed the maximum total phenols (Fig. 2), but the days when the maximum total phenol values occurred did not coincide with those for the maximum absorbances at $520 \mathrm{~nm}$. The maximum values of total phenols were higher in the musts with a higher dose of $\mathrm{SO}_{2}$. These results indicated that $\mathrm{SO}_{2}$ bleached the red pigments extracted from roselle calyces, although it also helped release the pigments from the tissues.

Changes during storage in the general composition of roselle red wine with different $\mathrm{pHs}$ and different concentrations of $\mathrm{SO}_{2}$ The above results showed that the addition of $\mathrm{SO}_{2}$ to the must greatly delayed the start of fermentation. Because no spoilage of roselle wines made from the musts without $\mathrm{SO}_{2}$ occurred during the vinification and storage processes (data not shown), roselle red wine was made without adding $\mathrm{SO}_{2}$ to the must in order to investigate the effects of $\mathrm{pH}$ and $\mathrm{SO}_{2}$ on the stability of the red pigments during storage. The $\mathrm{pH}$ and the absorbances at 520 and 420 $\mathrm{nm}$ of the red wine produced were 2.72, and 14.92 and 6.79 , respectively.

Wines of different pHs (2.50 to 4.00) in the absence of $\mathrm{SO}_{2}$ and with different concentrations of added $\mathrm{SO}_{2}(0$ to $250 \mathrm{mg}$ / l) at the same $\mathrm{pH}(2.72)$ were stored at $25^{\circ} \mathrm{C}$, and their general composition was analyzed 35 months after the beginning of storage. The results are shown in Table 1. A high storage temperature $\left(25^{\circ} \mathrm{C}\right)$ was used to promote changes in the red pigments during a relatively short period. Little differences in specific gravity, alcohol, volatile acid, and reducing sugar were observed between the wines when bottled and after storage for 35 months. However, among the wines in which the $\mathrm{pH}$ was adjusted, the $\mathrm{pH}$ values of the two wines with the highest $\mathrm{pHs}$ prior to storage changed from 3.50 to 3.38 and 4.00 to 3.82 , respectively. In the case of $\mathrm{SO}_{2}$ treatment, when a higher amount of $\mathrm{SO}_{2}$ was added, a slightly higher volatile acid content was found. When less than $150 \mathrm{mg} / l$ of $\mathrm{SO}_{2}$ was added at bottling, wines stored for 35 months had very little free $\mathrm{SO}_{2}$. The addition of $150 \mathrm{mg} / l$ of $\mathrm{SO}_{2}$ gave $16 \mathrm{mg} / l$ of free $\mathrm{SO}_{2}$ in the stored wine, which is a common concentration of free $\mathrm{SO}_{2}$ in grape wine.

Changes during storage in color parameters of roselle red wines of different $\mathrm{pHs}$ and with different concentrations of $\mathrm{SO}_{2}$ Red wine color at wine $\mathrm{pH}$ is due to anthocyanins and oligomeric and polymeric pigments (Somers \& Evans, 1977; Jackson et al., 1978; Yokotsuka, 1995). As red wine ages, the oligomeric and tannin-pigment polymers or polymerized compounds increase. The addition of $\mathrm{SO}_{2}$ to finished wine results in temporary color reduction by a reversible reaction between $\mathrm{SO}_{2}$ and the carbon 4 of a colored flavylium ion of anthocyanin to form colorless anthocyanin-4-bisulfite (Jurd, 1964). On the other hand, it prevents the formation of insoluble polymeric pigments due to oxidative browning reactions or polymerization during aging. The effect of $\mathrm{SO}_{2}$ on the red pigments or color parameters of the roselle wines was thus investigated (Table 2).

Red wine color (WC, $A_{520}$ ) at each wine $\mathrm{pH}$ and at $\mathrm{pH} 3.70$ (the $\mathrm{pH}$ of all the wines was adjusted to the same $\mathrm{pH}$ for comparison) and color density $\left(\mathrm{CD}, A_{520}+A_{420}\right)$ at wine $\mathrm{pH}$ of the stored wines decreased with increasing $\mathrm{pH}$ among the wines of different $\mathrm{pH}$ and also among the wines with different $\mathrm{SO}_{2}$ concentrations (Table 2). As expected, the wine color at pH 0.25 (WCA, $A_{520}$ ) and total phenols increased with increasing $\mathrm{SO}_{2}$ concentration. From these results, it was concluded that $\mathrm{SO}_{2}$ undoubtedly helps protect red pigments and other flavonoid phenolics in wine by preventing the formation of insoluble complexes due to oxidative polymerization. Thus, wine color (WC) and polymeric pigment color (PPC, $A_{520}$ at wine $\mathrm{pH}$ in the presence of excess $\mathrm{SO}_{2}$ ) significantly decreased with an increase in $\mathrm{SO}_{2}$ among the wines with different $\mathrm{SO}_{2}$ concentrations. The bisulfite anion reacts with the colored anthocyanin cation to form a colorless

Table 1. General composition of roselle red wines.

\begin{tabular}{|c|c|c|c|c|c|c|c|c|}
\hline & $\mathrm{pH}$ & $\begin{array}{l}\text { Specific } \\
\text { gravity }\end{array}$ & $\begin{array}{l}\text { Alcohol } \\
(\%, v / v)\end{array}$ & $\begin{array}{c}\text { Total acid } \\
\text { (as } \mathrm{H}_{2} \mathrm{SO}_{4}, \mathrm{~g} / 100 \mathrm{ml} \text { ) }\end{array}$ & $\begin{array}{c}\text { Volatile acid } \\
\text { (as acetic acid, } \mathrm{g} / 100 \mathrm{ml} \text { ) }\end{array}$ & $\begin{array}{c}\text { Reducing sugar } \\
\text { (as glucose, } \mathrm{g} / 100 \mathrm{ml} \text { ) }\end{array}$ & $\begin{array}{c}\text { Total } \mathrm{SO}_{2} \\
(\mathrm{mg} / l)\end{array}$ & $\begin{array}{c}\text { Free } \mathrm{SO}_{2} \\
(\mathrm{mg} / l)\end{array}$ \\
\hline \multicolumn{9}{|c|}{$\mathrm{pH}$ of wine at the beginning of storage $\mathrm{e}^{a)}$} \\
\hline 2.5 & 2.51 & 1.002 & 10.9 & 1.07 & 0.057 & 1.48 & - & - \\
\hline 2.8 & 2.79 & 1.002 & 10.6 & 0.93 & 0.057 & 1.49 & - & - \\
\hline 3.0 & 2.95 & 1.002 & 10.5 & 0.86 & 0.058 & 1.49 & - & - \\
\hline 3.5 & 3.38 & 1.002 & 10.6 & 0.64 & 0.055 & 1.48 & - & - \\
\hline 4.0 & 3.82 & 1.002 & 10.7 & 0.47 & 0.057 & 1.44 & - & - \\
\hline \multicolumn{9}{|c|}{$\mathrm{SO}_{2}(\mathrm{mg} / l)$ added at the beginning of storage ${ }^{b)}$} \\
\hline 0 & 2.79 & 1.002 & 10.6 & 0.93 & 0.057 & 1.48 & 0 & 0 \\
\hline 50 & 2.81 & 1.002 & 10.5 & 0.93 & 0.058 & 1.43 & 3 & 1 \\
\hline 100 & 2.79 & 1.002 & 10.6 & 0.95 & 0.064 & 1.38 & 43 & 3 \\
\hline 150 & 2.79 & 1.002 & 10.6 & 0.95 & 0.066 & 1.41 & 88 & 16 \\
\hline 250 & 2.79 & 1.002 & 10.4 & 0.96 & 0.073 & 1.41 & 193 & 72 \\
\hline
\end{tabular}

The wines were analyzed after storage at $25^{\circ} \mathrm{C}$ in the dark for 35 months.

a) $\mathrm{The} \mathrm{pH}$ was adjusted to a value between 2.5 and 4.0 just before bottling and storage after fermentation at $25^{\circ} \mathrm{C}$ using roselle must with a pH of 2.81 and without $\mathrm{SO}_{2}$

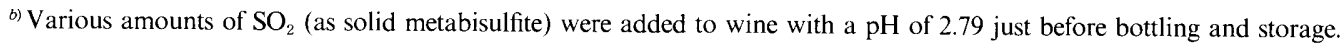


Table 2. Spectral and phenolic analyses of roselle red wines.

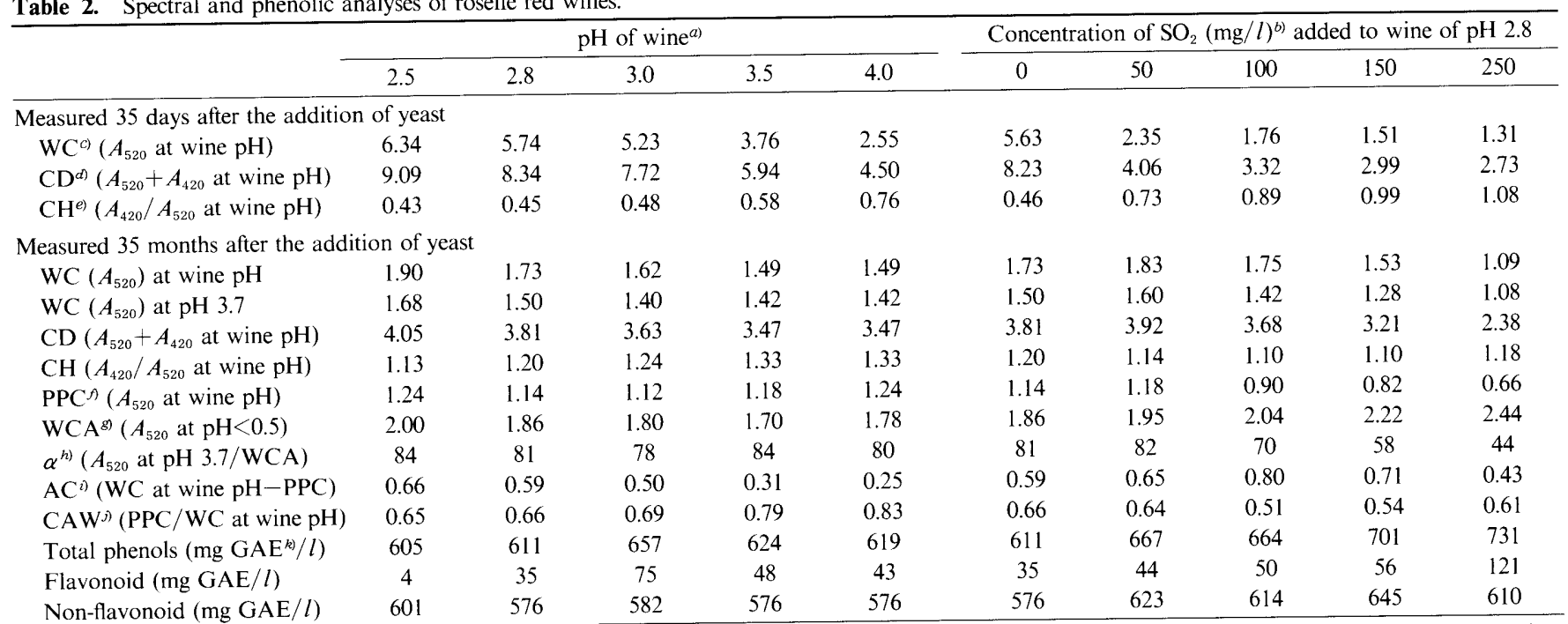

a,b) See footnote of Table $1 .{ }^{c}$ Wine color. ${ }^{d)}$ Color density. ${ }^{e)}$ Color hue. ${ }^{f)}$ Polymeric pigment color. ${ }^{g}$ Wine color in acid (at pH 0.25 ). ${ }^{h)}$ Degree of pigment coloration.

i) Anthocyanin color. ${ }^{\jmath)}$ Chemical age at wine $\mathrm{pH}$. ${ }^{k}$ Gallic acid equivalent.

species, anthocyanin-4-bisulfite (Jurd, 1964). Because the carbon 4 of anthocyanin-4-sulfite is involved in bond formation between anthocyanin and other flavonoids, such sulfites are less reactive, and the formation of polymeric pigments might thus be reduced.

Color hue ( $\mathrm{CH}, A_{420} / A_{520}$ at wine $\mathrm{pH}$ ), a measure of wine browning, increased with increasing $\mathrm{pH}$ among the wines of different $\mathrm{pH}$, but did not appreciably vary among the wines with different $\mathrm{SO}_{2}$ concentrations. The color hues of the wines in the $\mathrm{SO}_{2}$-treated group ranged from 1.10 to 1.20 . These values are similar to those of aged or over-aged grape wines (Somers \& Evans, 1977; Yokotsuka, 1995). The higher color hue observed in the $\mathrm{SO}_{2}$-treated wines soon after vinification ( 35 days after the addition of yeast) may be due to a reduction of the $A_{520}$ by the temporary decolorization of red pigments.

The degree of coloration of total wine pigments at $\mathrm{pH} 3.7$ ( $\alpha$ ) (Somers \& Evans, 1974, 1977; Timberlake, 1982; Bakker \& Timberlake, 1986) did not vary in the wines stored under different $\mathrm{pHs}$, but decreased with increasing $\mathrm{SO}_{2}$ in the $\mathrm{SO}_{2}$-treated wines. The degree of coloration was strongly correlated with the concentration of free $\mathrm{SO}_{2}$.

Two color parameters, the chemical age at wine $\mathrm{pH}(\mathrm{CAW}$, $A_{520}^{\mathrm{SO}_{2}} / A_{520}^{\mathrm{pH}<0.5}$ ) (Somers \& Evans, 1974, 1977) and the anthocyanin color (AC), are related to the contribution of polymeric pigments or anthocyanins to wine color. With increasing $\mathrm{pH}$ in the wines, $\mathrm{AC}$ decreased, but $\mathrm{CAW}$ increased. This means that the contribution of polymeric pigments to wine color increased with increasing storage $\mathrm{pH}$. On the other hand, after storage for 35 months in the presence of various concentrations of $\mathrm{SO}_{2}$, the lowest $\mathrm{CAW}$ and highest $\mathrm{AC}$ values were obtained at $100 \mathrm{mg} \mathrm{SO} / l$.

The main stability problem with phenols, including red pigments in red wine, is directly attributable to oxidation problems. In general, a lower $\mathrm{pH}$ and higher $\mathrm{SO}_{2}$ make wine less liable to oxidation because the oxidation reaction of the phenols proceeds more rapidly at a higher $\mathrm{pH}$, and oxygen in wine is reduced by $\mathrm{SO}_{2}$. In the present work, as expected, the
Table 3. Taster's scores for roselle red wines.

\begin{tabular}{|c|c|c|c|c|}
\hline & $\begin{array}{l}\text { Color } \\
(0-5)\end{array}$ & $\begin{array}{c}\text { Aroma } \\
(0-5)\end{array}$ & $\begin{array}{l}\text { Flavor } \\
(0-10)\end{array}$ & $\begin{array}{c}\text { Overall quality } \\
(0-20)\end{array}$ \\
\hline \multicolumn{5}{|c|}{$\mathrm{pH}$ of wine at the beginning of storage ${ }^{a)}$} \\
\hline 2.5 & 3.3 & 2.6 & 3.5 & 9.4 \\
\hline 2.8 & 3.4 & 2.6 & 3.5 & 9.5 \\
\hline 3.0 & 3.0 & 2.6 & 3.6 & 9.2 \\
\hline 3.5 & 2.7 & 2.6 & 3.7 & 9.0 \\
\hline 4.0 & 2.6 & 2.6 & 2.9 & 8.1 \\
\hline \multicolumn{5}{|c|}{$\mathrm{SO}_{2}(\mathrm{mg} / l)$ added at the beginning of storage ${ }^{b)}$} \\
\hline 0 & 3.4 & 2.6 & 3.5 & 9.5 \\
\hline 50 & 3.0 & 2.8 & 3.5 & 9.3 \\
\hline 100 & 3.4 & 2.9 & 3.7 & 10.0 \\
\hline 150 & 3.2 & 2.6 & 3.3 & 9.1 \\
\hline 250 & 2.6 & 2.2 & 3.3 & 8.1 \\
\hline
\end{tabular}

Color ( 5 good, 3 fair, 0 poor); Aroma ( 5 good, 3 fair, 0 poor); Flavor (10 complex/good, 5 not deficient/fair, 0 flat/poor); Overall quality (20 excellent, 15 good, 10 fair, 5 poor).

a,b) See footnote of Table 1.

total, flavonoid and non-flavonoid phenols increased with increasing $\mathrm{SO}_{2}$ in the $\mathrm{SO}_{2}$-treated wine. In contrast, in the wines with $\mathrm{pHs}$ of $3.0,3.5$, and 4.0 at the beginning of storage, the total and flavonoid phenols decreased with increasing $\mathrm{pH}$. The wines with pHs of 2.5 and 2.8 had less total and flavonoid phenols than those with higher pHs (3.0, 3.5, and 4.0) Although no definite explanation for this can be advanced, it may be related with the finding that grape seed polymeric tannins remained less soluble in a wine-like model solution (10\% ethanol) with a $\mathrm{pH}$ of 2.5 than in solutions with higher pHs (3.0 to 4.5) (Yokotsuka \& Singleton, 1987, 1995). The degree of polymerization of phenols in the five wines with different $\mathrm{pHs}$ is thought to have been rather high; the proportion of polymeric pigments in the wine color (WC) at wine $\mathrm{pH}$ reached 65 to $83 \%$, with an average of $72 \%$ (Table 2).

Quality rating Somers and Evans $(1974,1977)$ reported strong correlations between color density and quality 
ranking in young Australian wines. Also, in comparative studies of young and aging red wines made from Cabernet Sauvignon and Muscat Bailey A grapes in Japan, Yokotsuka (1995) found that visual assessment of color significantly correlated with taster assessment of overall quality and with instrumental measurements of pigment parameters at wine $\mathrm{pH}$, such as wine color, color density, and polymeric pigment color. In the roselle wines adjusted to different $\mathrm{pHs}$ from 2.5 to 4.0 or to which different amounts of $\mathrm{SO}_{2}$ from 0 to $250 \mathrm{mg}$ / $l$ were added when bottled, there was always a good relationship [correlation coefficient $(r)=0.863, p<0.10$, for the 5 wines stored under different $\mathrm{pHs} ; r=0.869, p<0.10$, for the 5 wines stored with different concentrations of $\mathrm{SO}_{2}$ ] between taster assessment of overall quality (color+flavor+aroma) (Table 3) and anthocyanin color [ AC (anthocyanin color) $=$ WC (wine color at wine $\mathrm{pH}$ ) - $\mathrm{PPC}$ (polymeric pigment color at wine $\mathrm{pH})$ ] (Tables 2 and 3). There was also a good correlation ( $r=0.859, p<0.10$, for the 5 wines stored under different pHs; $r=0.918, p<0.05$, for the 5 wines stored with different concentrations of $\mathrm{SO}_{2}$ ) between visual assessment of color and overall quality. Red wine color is influenced by $\mathrm{pH}$ and $\mathrm{SO}_{2}$ : the higher the $\mathrm{pH}$ and the higher the $\mathrm{SO}_{2}$ concentration under which the red wines are stored, the lower the intensity of the red color. Instrumental measurement of color parameters is, therefore, very important in investigating the effects of $\mathrm{pH}$ and $\mathrm{SO}_{2}$ on wines during storage. In the present work, spectral analysis of pigment parameters and visual assessment of red wine color significantly correlated with taster assessment of overall quality.

\section{References}

Amerine, M.A. and Ough, C.S. (1980). "Methods for Analysis of Musts and Wines." John Wiley and Sons, New York.

Bakker, J. and Timberlake, C.F. (1986). The mechanism of colour changes in aging port wine. Am. J. Enol. Vitic., 37, 288-292.

Burroughs, L. and Whiting, G.C. (1960). The sulphur dioxide combining power of cider. Annu. Report Agric. Hort. Exp. Station. Long Ashton, U.K., pp. 144-147.

Du, C.T. and Francis, F.J. (1973). Anthocyanins of roselle (Hibiscus sabdariffa, L.). J. Food Sci., 38, 810-812.

El-Merzabani, M.M., El-Aaser, A.A., Attia, M.A., El-Duweini, A.K. and Ghazal, A.M. (1979). Screening system for Egyptian plants with potential anti-tumour activity. Planta Med., 36, 150-155.

El-Shaveb, N.M. A. and Mabrouk, S.S. (1984). Utilization of some edible and medical plants to inhibit aflatoxin formation. Nutr. Rep. Int., 29, 273-282.

Jackson, M.G., Timberlake, C.F., Bridle, P. and Vallis, L. (1978). Red wine quality: correlations between colour, aroma and flavors and pigment, and other parameters of young Beaujolais. J. Sci. Food Agric, 29, 715-727.

Jurd, L. (1964). Reactions involved in sulfite bleaching of anthocyanins. J. Food Sci., 29, 16-19.

Kramling, T.E. and Singleton, V.L. (1969). An estimate of the nonflavonoid phenols in wines. Am. J. Enol. Vitic., 20, 86-91.

Leclerc, H. (1938). A propos du Thé rose ou Sida Sabdariffa. Presse Med., 46, 1060 .

Perry, L.M. (1980). "Medical Plants of East and Southeast Asia." MIT Press, Cambridge, MA, p. 254.

Sharaf, A. (1962). The pharmacological characteristics of Hibiscus sabdariffa L. Planta Med., 10, 48-52.

Shibata, M. and Furukawa, M. (1969). Reexamination on the structure of so-called "Hiviscin." Bot. Mag. Tokyo, 82, 341-347.

Slinkard, K. and Singleton, V.L. (1977). Total phenol analysis: automation and composition with manual methods. Am. J. Enol. Vitic., 20, 86-91.

Somers, T.C. and Evans, M.E. (1974). Wine quality: correlations with colour density and anthocyanin equilibria in a group of young red wines. J. Sci. Food Agric., 25, 1369-1379.

Somers, T.C. and Evans, M.E. (1977). Spectral evaluation of young red wines: anthocyanins equilibria, total phenolics, free and molecular $\mathrm{SO}_{2}$, chemical age. J. Sci. Food Agric., 28, 279-287.

Timberlake, C.F. (1982). Factors affecting red wine colour: the use of a "coloration" constant in evaluating red wine color. Symposium proceedings, Grape and Wine Centennial. Univ. of California, Davis CA, 18-21 June 1980, pp. 240-244.

Yokotsuka, K. (1995). Changes in color during aging of Cabernet Sauvignon and Muscat Bailey A red wines: I. Spectral analysis of pigment parameters. J. Brew. Soc. Jpn., 90, 222-229.

Yokotsuka, K. and Matsudo, T. (1992). Comparison of composition of wines made using liquid starters Saccharomyces cerevisiae W3 and $\mathrm{OC} 2$ and active dry yeast forms of the same strains. J. Inst. Enol. Vitic. Yamanashi Univ., 27, 1-5.

Yokotsuka, K. and Singleton, V.L. (1987). Interactive precipitation between graded peptides from gelatin and specific grape tannin fractions in wine-like model solutions. Am. J. Enol. Vitic., 38, 199206.

Yokotsuka, K. and Singleton, V.L. (1995). Interactive precipitation between phenolic fractions and peptides in wine-like model solutions: turbidity, particle size, and residual content as influenced by $\mathrm{pH}$, temperature and peptide concentration. Am. J. Enol. Vitic., 46, 329-338 